\author{
Praca poglądowa/Review paper
}

\title{
Radiobiologia: podstawowe modele matematyczne opisujące przeżywalność komórek
}

\author{
Wiktoria Suchorska ${ }^{1}$ \\ ${ }^{1}$ Pracownia Radiobiologii, Wielkopolskie Centrum Onkologii, Poznań, Polska
}

\section{Streszczenie}

Krzywa przeżywalności komórek opisuje zależność pomiędzy dawką promieniowania jonizującego a liczbą komórek, które przeżyły. W przypadku nowotworów, które mają być wyeliminowane z organizmu konieczne jest zabicie komórek w rozumieniu definicji radiobiologicznej, tj. pozbawienie ich zdolności proliferacji, która odpowiada za rozprzestrzenianie się i wzrost agresywności. jakościowy opis krzywych przeżywalności komórek po działaniu promieniowania jonizującego jest stosunkowo prosty, jednak wyjaśnienie odpowiedzi biologicznej w kontekście zjawisk biofizycznych wymaga wprowadzenia modeli teoretycznych, które nie zawsze idealnie odzwierciedlają dane eksperymentalne. Celem niniejszej pracy jest opisanie najczęściej stosowanych modeli matematycznych opisujących kształt krzywej przeżywalności komórek ssaczych.

\begin{abstract}
The cell survival curve describes the relationship between the dose of ionizing radiation and the number of surviving cells. In tumour the cells should be eliminated within the meaning of the radiobiological definition: by deprivation of their ability to proliferate, which is responsible for the spread and increase of aggressiveness. Qualitative description of cell survival curves after ionizing radiation is relatively simple, but the explanation of the biological response in the context of biophysical phenomena requires the introduction of theoretical models that do not always perfectly reflect the experimental data. The main aim of this article is to explain the most commonly used mathematical models describing the shape of the survival curve of mammalian cells.
\end{abstract}

Stowa kluczowe: krzywa przeżywalności komórek, model liniowo-kwadratowy

Keywords: cell survival curve, linear-quadratic model

Adres do korespondencji

Wiktoria Suchorska

Pracownia Radiobiologii

Wielkopolskie Centrum Onkologii, ul. Garbary 15, 61-866 Poznań, Polska

Telefon. +48618850477

e-mail: wiektoria.suchorska@wco.pl 


\section{Wstęp}

Krzywa przeżywalności komórek opisuje zależność pomiędzy dawką promieniowania jonizującego a liczbą komórek, które przeżyły. Pojęcie przeżycia (ang. survival, S) i śmierci komórek może mieć różne definicje w zależności od kontekstu. Komórki zróżnicowane, które nie proliferują (np. komórki mięśni, komórki nerwowe czy komórki wydzielnicze) uważane są za martwe wówczas, kiedy utracą swoją funkcję. Natomiast w przypadku komórek dzielących się (komórki macierzyste układu krwiotwórczego, czy komórki nabłonka jelit) śmierć oznacza utratę zdolności do proliferacji, czyli utratę integralności reprodukcyjnej. Niekiedy mówi się o tzw. śmierci reprodukcyjnej. Jest to mierzony punkt końcowy (ang. end point) w eksperymentach prowadzonych w hodowlach komórkowych in vitro. Taka zawężona definicja przeżycia i śmierci komórek funkcjonuje w radiobiologii. Oznacza to, że komórki mogą być obecne w środowisku, oddziaływać ze sobą, a nawet być zdolne do przejścia jednego czy dwóch kolejnych podziałów mitotycznych. Niemniej jednak, komórki które utraciły zdolność do nieograniczonego podziału i wytwarzania dużej liczby komórek potomnych z zasady uważane są za martwe. Komórki, które przeżyją działanie promieniowania jonizującego, zachowają możliwość podziału i produkowania tzw. kolonii komórek nazywa się komórkami klonogennymi (ang. clonogenic) [1]. Ta definicja znajduje zastosowanie w radiobiologii zwierząt, roślin i ich tkanek, także nowotworowych.

W przypadku nowotworów, które mają być wyeliminowane zorganizmu konieczne jest zabicie komórek w rozumieniu definicji radiobiologicznej, tj. pozbawienie ich zdolności proliferacji, która odpowiada za rozprzestrzenianie się i wzrost agresywności. Opisano różne mechanizmy śmierci komórkowej [2]. W przypadku większości komórek poddanych działaniu promieniowania jonizującego śmierć następuje na skutek nieprawidłowego podziału, tj. w wyniku tzw. katastrofy mitotycznej. Wykazano, że aby zniszczyć funkcje komórek niedzielących się konieczne jest napromienienie dawką 100 Gy, natomiast w przypadku komórek proliferujących średnia dawka letalna wynosi zaledwie 2 Gy [3].

Zdolność pojedynczej komórki do utworzenia kolonii komórek widocznych nieuzbrojonym okiem (bez użycia mikroskopu) jest wystarczającym dowodem na zachowanie przez tę komórkę właściwości reprodukcyjnych. Utrata tej zdolności w funkcji dawki jest opisywana krzywą przeżywalności (ang. dose-survival curve). Wyznaczanie krzywych przeżywalności komórek w zależności od dawki promieniowania jest jednym z najprostszych, ale fundamentalnych eksperymentów radiobiologicznych (Ryc. 1).

Komórki adherentne (czyli przyklejone do powierzchni hodowlanej) po napromienieniu określoną dawką są przenoszone do zawiesiny za pomocą roztworu trypsyny, który powoduje odklejenie komórek od naczynia. Następnie komórki są liczone i ustalona liczba komórek jest wysiewana na nowe naczynie hodowlane. Hodowla jest prowadzona przez kolejne tygodnie (1 do 3, w zależności od rodzaju komórek). Komórki, które zachowały zdolność do podziałów tworzą widoczne kolonie. Wszystkie komórki w kolonii pochodzą od pojedynczej komórki, która przeżyła zadaną dawkę. Test klonogenny wykonuje się zawsze w odniesieniu do kontroli, tj. komórek, które nie były napromieniane

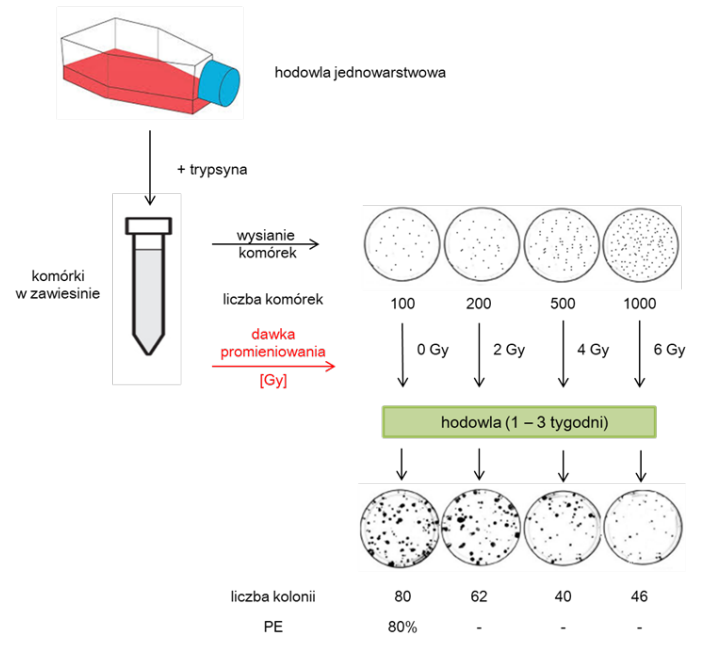

Rycina 1 (ang. sham) po to, aby określić początkową wydajność hodowli (ang. plating efficiency, $P E$ ).

Wydajność hodowli oblicza się ze wzoru:

$$
P E=\frac{\text { liczba kolonii na płytce }}{\text { liczba wysianych komórek }} \times 100
$$

Przykład:

Jeżeli wysiano 100 komórek w kontroli, następnie po zakończeniu testu na tej samej płytce (nienapromienianej) policzono 60 kolonii, oznacza to, że wydajność hodowli wynosi: $\mathrm{PE}=(60 / 100) \times 100=60 \%$. Równocześnie należy założyć hodowlę komórek, które będą napromieniane. Zwykle liczba wysiewanych komórek jest większa niż w kontroli, należy jednak ustalić ją eksperymentalnie dla danego rodzaju hodowli. Frakcję komórek 
przeżywających (ang. surviving fraction, SF) (lub inaczej: współczynnik przeżycia komórek) oblicza się zgodnie ze wzorem:

$$
S F=\frac{\text { liczba kolonii na płytce }}{\text { liczba komórek wysianych } x\left(\frac{P E}{100}\right)}
$$

Cały eksperyment powtarza się dla wybranych dawek (Ryc. 1). Liczba komórek dla danego testu i liczba powtórzeń jest ustalana eksperymentalnie dla zakresu badanych dawek: zbyt mała liczba obniża istotność statystyczną wyników, zbyt wysoka uniemożliwia prawidłowe zliczenie kolonii.

\section{Kształt krzywych przeżywalności}

Krzywe zależności przeżywalności komórek ssaczych od dawki zwykle przedstawiane są w postaci liniowokwadratowej, gdzie przeżywalność jest oznaczona w skali logarytmicznej. Kształt krzywej przeżywalności zależy od rodzaju promieniowania (ryc. 2). W przypadku niskich dawek promieniowania słabo jonizującego (ang. sparsely ionizing), $\mathrm{tj}$. o małym współczynniku liniowego przekazywania energii (ang. linear energy transfer, LET), krzywa przeżywalności ma początkowo kształt prostej o skończonym nachyleniu początkowym. Oznacza to, że współczynnik przeżycia komórek (SF) jest wykładniczą funkcja dawki. Ze wzrostem dawki wykres przechodzi w krzywą, której nachylenie wzrasta w zakresie dawek do kilku grejów. Krzywa przeżycia komórek ma tendencję do ponownego przybierania kształtu prostej w przypadku wysokich dawek promieniowania. W praktyce klinicznej taka sytuacja miałaby miejsce wówczas, gdyby dzienna dawka frakcyjna przekraczała 2 Gy. Stosowanie promieniowania wywołującego gęstą jonizację ośrodka (ang. densely ionizing) o dużym współczynniku LET, np. cząstek $\alpha$, powoduje, że kształt krzywej przeżywalności jest zbliżony do linii prostej, zatem współczynnik przeżycia komórek jest wykładniczą funkcją dawki (ryc. 2) [4].

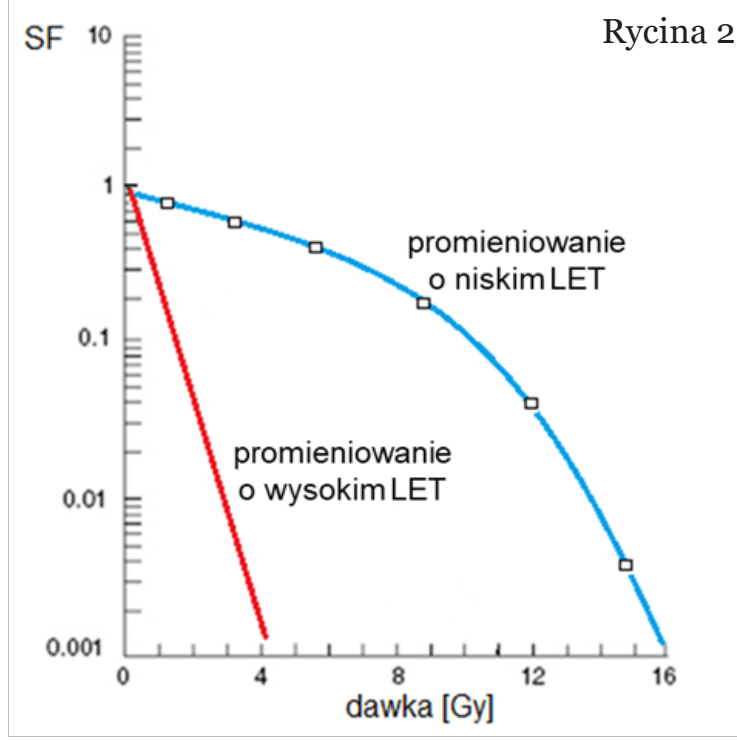

\section{Cel pracy}

Przedstawiony powyżej jakościowy opis krzywych przeżywalności komórek po działaniu promieniowania jonizującego jest stosunkowo prosty, jednak wyjaśnienie odpowiedzi biologicznej w kontekście zjawisk biofizycznych wymaga wprowadzenia modeli teoretycznych, które nie zawsze idealnie odzwierciedlają dane eksperymentalne.

Celem tej pracy jest opisanie najczęściej stosowanych modeli matematycznych opisujących kształt krzywej przeżywalności komórek ssaczych.

\section{Odpowiedź na promieniowanie jonizujące na poziomie molekularnym}

Promieniowanie jonizujące powoduje śmierć komórek poprzez wytworzenie wtórnie naładowanych cząstek i wolnych rodników w jądrze, które uszkadzają DNA [5]. Każdy 1 Gy promieniowanie jonizującego o niskim LET powoduje około 1000 uszkodzeń zasad DNA, około 1000 uszkodzeń pojedynczoniciowych (ang. single-strand breaks, SSB) oraz 20 - 40 uszkodzeń podwójnoniciowych (ang. double-strand breaks, DSB). Śmiertelność komórek wywołana promieniowaniem jonizującym związana jest przede wszystkim z liczbą nienaprawionych uszkodzeń typu DSB [6]. Jeżeli śmiertelność komórek jest modyfikowana przez zamianę LET, poziomu utlenowania, stężenia grup tiolowych, czy temperaturę, to dla takiej samej ustalonej dawki liczba DSB koreluje z liczbą komórek zabitych. Uszkodzenia DNA typu SSB, uszkodzenia zasad nukleotydowych czy wiązania krzyżowe DNA-białko nie odzwierciedlają zmian w populacji zabitych komórek dla żadnych z wymienionych radiouczulaczy i radioprotektorów. Zatem podwójnoniciowe uszkodzenia DNA są uważane za najbardziej „śmiercionośne” uszkodzenie komórki. W szczególnych przypadkach 
(komórki bardzo wrażliwe, odpowiedź na bardzo niskie dawki, czy odpowiedź na promieniowanie o wysokim LET) wystarczy jedno uszkodzenie typu DSB w łańcuchu DNA (jedno „trafienie”, ang. one 'hit'), aby doprowadzić do znaczących aberracji chromosomowych i, w konsekwencji, do sterylizacji komórki [7].

\section{Teoria tarczy a model jednotarczowy}

W DNA występują sekwencje, które odpowiadają za utrzymanie zdolności reprodukcyjnych komórek. Teoria tarczy opiera się na tym, że uszkodzenie promieniowaniem jonizującym tych specyficznych rejonów powoduje inaktywację komórki, czyli utratę klonogenności. Początkowo zakładano, że jedno trafienie w tarczę za pomocą promieniowania jonizującego prowadzi do śmierci komórki. Zjawisko to opisano matematycznie za pomocą modelu jednotarczowego (ang. single-target single-hit model), a krzywa ma kształt prostej (ryc. 3) [8].

Aby otrzymać równanie krzywej przeżywalności dla modelu jednotarczowego należy zastosować statystykę Poissona. Statystyka Poissona opiera się na założeniu, że podczas napromieniania komórek następuje bardzo duża liczba trafień w różne komórki, ale prawdopodobieństwo (p) ponownego trafienia w tę samą komórkę jest bardzo małe.

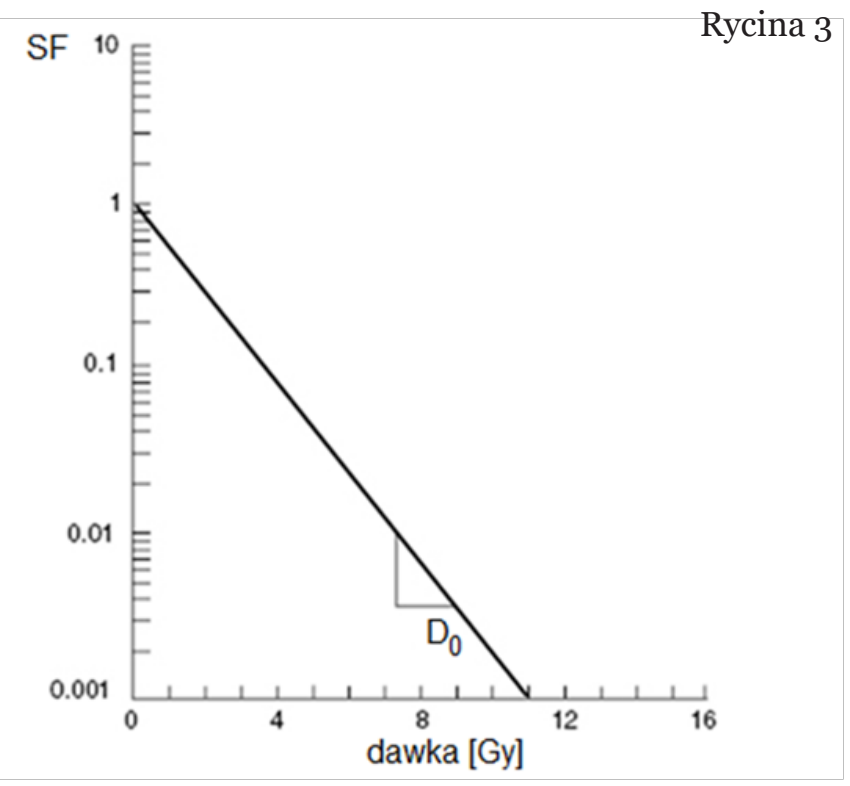

Stąd, dla każdej komórki:

$$
p(\text { przeżycia })=p(S)=p(0 \text { trafień })=\exp \left(-D / D_{o}\right)
$$

gdzie $\mathrm{D}_{0}$ jest dawką, przy której średnio występuje jedno trafienie na jeden cel (każda komórka otrzymuje jedno trafienie), $\mathrm{D} / \mathrm{D}_{0}$ jest średnią liczbą trafień w tarczę (w komórkę). Zgodnie z definicją funkcji wykładniczej $\left(y=e^{x}\right.$, $\exp (x))$ dawka $\mathrm{D}_{\mathrm{o}}$ obniża liczbę komórek przeżywających z 1 do $0,37\left(\mathrm{e}^{-1}=0,367 \ldots\right)$ lub z 0,1 do 0,037 itd.

\section{Model wielotarczowy}

Model wielotarczowy (ang. multitarget model) był stosowany w radiobiologii wiele lat i pewne jego elementy są ciągle prawdziwe [9]. W tym modelu pojawiają się dodatkowe zmienne. Nachylenie początkowe krzywej przeżywalności (z ang. tzw. initial slope) zależy od pojedynczego śmiertelnego trafienia w tarczę (single-hit przy dawce $\mathrm{D}_{1}$ ), natomiast końcowe nachylenie (z ang. tzw. final slope), od wielu trafień (multi-hit przy dawce $\mathrm{D}_{\mathrm{o}}$ ). Ponadto, występuje wielkość $\mathrm{D}_{\mathrm{q}}$ (ekstrapolowana do n), która charakteryzuje szerokość ramienia krzywej przeżywalności (Ryc. 4a). Model wielotarczowy jest stosowany do opisu odpowiedzi biologicznej komórek ssaczych na wysokie dawki promieniowania jonizującego. Liczbowo wielkości $\mathrm{D}_{1}$ i $\mathrm{D}_{0}$ są zależne od początkowego i końcowego nachylenia krzywej przeżywalności komórek. W obu przypadkach określają one dawkę, przy której następuje obniżenie przeżywalności komórek o 37\% $(0,37)$ w stosunku do wartości pierwotnej. Jak pokazano na ryc. 4 wartość $\mathrm{D}_{1}$ jest dawką, którą należy podać, aby obniżyć przeżywalność komórek do $0,37 \mathrm{w}$ początkowym przebiegu krzywej, natomiast wartość $\mathrm{D}_{0}$ jest dawką, którą należy podać, aby obniżyć przeżywalność w końcowym przebiegu krzywej z 0,1 do 0,037 lub z 0,01 do 0,037 itd. Ponieważ liczba komórek jest oznaczana w skali logarytmicznej, a krzywa przeżywalności zbliża się do prostej dla wyższych dawek, to dawka potrzebna do zmniejszenia populacji komórek (do wartości 0,37) jest taka sama niezależnie od liczności populacji wyjściowej. Wielkość ekstrapolowana n jest miarą „szerokości” ramienia krzywej (im większe n, tym szersza krzywa). Inną miara szerokości krzywej jest tzw. dawka quasi-progowa (ang. quasitreshold dose) $\mathrm{D}_{\mathrm{q}}$, czyli taka dawka, w której prosta część krzywej przeżywalności, ekstrapolowana „do tyłu”, przecina oś SF w punkcie 1 (Ryc. 4b). Dawka progowa, to jest taka dawka, poniżej której nie obserwuje się efektu biologicznego [10].

W praktyce dawka progowa nie istnieje, ponieważ nie można powiedzieć, że promieniowanie jonizujące nie 

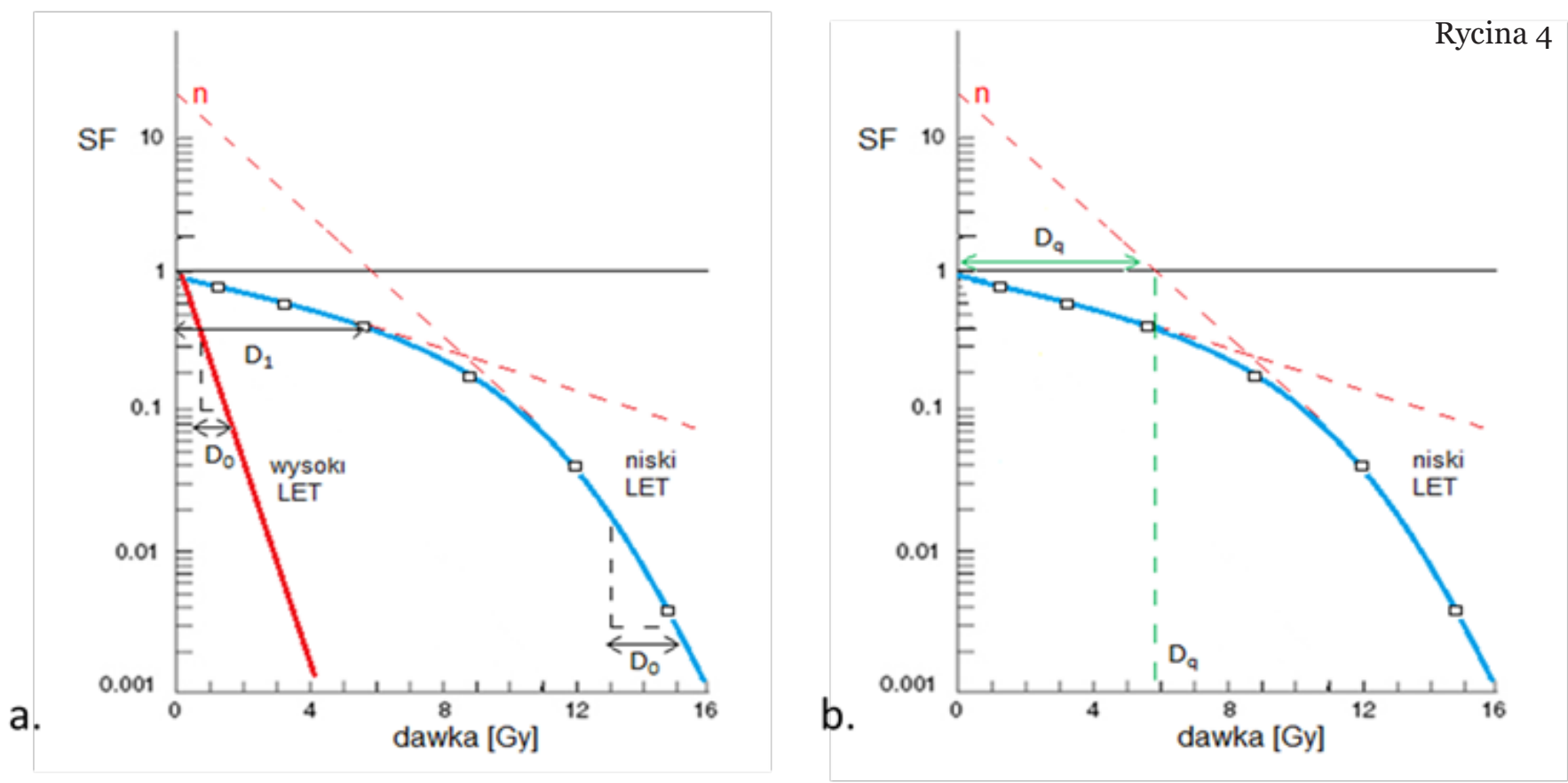

wywołuje skutków poniżej określonej dawki. Parametry opisujące model wielotarczowy są zależne od siebie zgodnie z wyrażeniem:

\section{Model liniowo-kwadratowy}

$$
\log _{e} n=D_{q} / D_{o}
$$

Modelem matematycznym, który jest obecnie stosowany $\mathrm{z}$ wyboru do opisu zdarzeń biologicznych po podaniu dawki promieniowania jonizującego jest model liniowo-kwadratowy (ang. linear-quadratic model, LQ) [11]. W modelu tym założono występowanie dwóch stałych opisujących śmierć komórki na skutek działania określonej dawki. Pierwsza stała jest wprost proporcjonalna do zadanej dawki $(\alpha)$, a druga do kwadratu jej wielkości $(\beta)$. Wprowadzenie stałych, które mają wpływ na przeżywalność komórek i zależą od dawki i jej kwadratu wynika z mechanizmu działania promieniowania jonizującego: aberracje chromosomów, które są letalne dla komórki (np. chromosomy dicentryczne, mostki anafazowe, pierścienie) są wywoływane przez uszkodzenia obu nici DNA.

Równanie opisujące kształt krzywej przeżywalności komórek w modelu liniowo-kwadratowym można najprościej zapisać wyrażeniem:

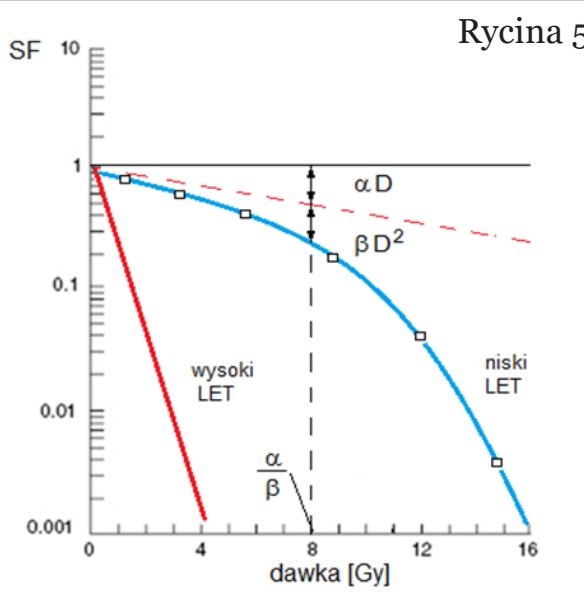

$$
\begin{aligned}
& -\ln (S)=\alpha D+\beta D^{2} \\
& p(\text { survival })=\exp \left(-\alpha D-\beta D^{2}\right) \\
& S=e^{-\alpha D-\beta D^{2}}
\end{aligned}
$$

gdzie S oznacza populację komórek, które przeżyły dawkę $D$, a wyrażenia $\alpha$ i $\beta$ są stałymi równania odpowiedzialnymi za uszkodzenia śmiertelne $(\alpha)$ i potencjalnie śmiertelne $(\beta)$. Równanie krzywej opisującej przeżywalność komórek w modelu LQ najlepiej charakteryzuje odpowiedź radiobiologiczną na dawki promieniowania jonizującego w zakresie $0-3$ Gy. Wykres przeżywalności (ryc. 5) jest pochylony w całym przebiegu i jest asymptotą krzywej LQ. Kształt krzywej („nachylenie”) zależy od stosunku uszkodzeń śmiertelnych (letalnych) $\alpha$ i potencjalnie śmiertelnych (subletalnych) $\beta$, czyli od wielkości $\alpha / \beta$, co wynika z:

$$
\alpha D=\beta D^{2}
$$

lub:

$$
D=\alpha / \beta
$$


Zatem należy podkreślić, że letalne i subletalne uszkodzenia komórek prze dane dawce są takie same przy dawce równej stosunkowi $\alpha / \beta$.

\section{Wnioski}

Model LQ w jego najbardziej aktualnej wersji opisuje zabicie komórek na skutek działania promieniowania jonizującego uwzględniając poniższe mechanizmy:

(a) Promieniowanie jonizujące powoduje powstanie dwuniciowych pęknięć DNA (DSB) proporcjonalnie do dawki.

(b) DSB DNA mogą zostać naprawione z stałą wydajnością $\lambda\left(\lambda=\ln 2 / T_{1 / 2}\right.$, gdzie $T_{1 / 2}$ jest połowicznym czasem naprawy). W praktyce może wystąpić więcej niż jeden typ DSB, które mogą być naprawiane z różnymi prędkościami. Model LQ może być rozszerzony do takich przypadków.

(c) W czasie naprawy DSB często występują błędy lub kolejne uszkodzenia wywołane inną ścieżką jonizacji (np. przez inny foton), co może powodować śmiertelne zmiany (najczęściej aberracje chromosomowe) proporcjonalnie do kwadratu dawki (por. wzór (6)). Dwie niezależne ścieżki jonizacji mogą się pojawić w różnym czasie w ciągu całego procesu leczenia. Umożliwia to naprawę pierwszego uszkodzenia typu DSB, zanim nastąpi kolejne, co leży u podstaw frakcjonowania dawki i jest istotą modelu LQ.

(d) Ponadto pojedyncze ścieżki jonizacji (trafienia) mogą wywoływać śmiertelne zmiany w komórce; ich mechanizm jest różny, ale wydajność powstawania jest liniowo proporcjonalna do dawki [12].

\section{Podsumowanie}

Mechanistyczny model liniowo-kwadratowy jest obecnie najczęściej stosowanym narzędziem do ilościowego szacowania zależności efektu od dawki i sposobu jej frakcjonowania w radioterapii (ponad 1600 artykułów w bazie PubMED). Wykorzystywany jest powszechnie do obliczania dawek izoefektywnych dla różnych schematów frakcjonowania leczenia, głównie dlatego, że jest oparty na danych uzyskanych w doświadczeniach biologicznych, a jednocześnie ma niewiele zmiennych, co powoduje, że znajduje zastosowanie praktyczne. Co więcej model LQ w wielu aspektach potwierdza prawidłowość innych bardziej skomplikowanych modeli mechanistycznych, a także własności predykcyjne dla frakcjonowania obliczane na podstawie zależności liniowo-kwadratowej zostały dobrze udokumentowane. Model ten jest walidowany do dawki frakcyjnej około $10 \mathrm{~Gy}$, postuluje się nawet, że zasadne byłoby jego stosowanie do dawki 18 Gy, jednak jak dotąd nie zostało to udowodnione w praktyce klinicznej.

\section{Konflikt interesu / Conflict of interest}

Nie występuje / None

\section{Finansowanie / Financial support}

Nie występuje / None

\section{Etyka / Ethics}

Treści przedstawione w artykule są zgodne z zasadami Deklaracji Helsińskiej, dyrektywami EU oraz ujednoliconymi wymaganiami dla czasopism biomedycznych.

\section{Piśmiennictwo / References}

[1] T. Puck i P. Marcus, „Action of x-rays on mammalian cells.”.J Exp Med. 1956;103:653-666.

[2] K. Kulcenty i W. M. Suchorska, „Biologiczne podstawy radioterapii środoperacyjnej,” w Radioterapia środoperacyjna, Gdańsk, ViaMedica, 2016.

[3] T. Beusker, A. Vergroesen, L. Budke i G. Barendsen, „Effects of different ionizing radiations on human 
cells in tissue culture. II. Biological experiments.," tom 13, nr 841-849, 1960.

[4] E. Hall i A. Giaccia, Radiobiology for the radiologist, Philadelphia: Lippincott Williams And Wilkins, a Wolters Kluwer buisness, 2012.

[5] D. Goodhead, „Energy deposition stochastics and track structure: what about the target?, Radiat Prot Dosimetry., 2006;122(1-4):3-15. Epub 2007 Feb 2.

[6] F. Ballarini, „From DNA Radiation Damage to Cell Death: Theoretical Approaches”.J Nucleic Acids. 2010; 2010: 350608..

[7] Z. Xurui, Y. Caiyong, S. Fang, W. Wenjun, H. Burong i W. Jufang, „Both Complexity and Location of DNA Damage Contribute to Cellular Senescence Induced by Ionizing Radiation”.PLoS One. 2016; 11(5): e0155725.

[8] J. Chapman, „Single-hit mechanism of tumour cell killing by radiation.”.Int J Radiat Biol. 2003 Feb;79(2):71-81.

[9] L. Zhao, M. Dong, H. Bei i S. Yeqing, „A generalized target theory and its applications”.Sci Rep. 2015; 5: 14568.

[10] S. Vijayakuma, C. Thian, I. Koumoundouros, P. Higgins i F. Thomas , „Less well known parameters of in vitro radiosensitivity.".J Natl Med Assoc. 1989 Jul; 81(7): 799-802.

[11] J. Fowler, „The linera-quadratic formula and progressin fractionated radiotherapy”.Br J Radiol. 1989 Aug; 62(740):679-94. 